\title{
POPRAWNOŚĆ POLITYCZNA PONAD WSZYSTKO? KILKA UWAG O ANTYNAUKOWYCH INKLINACJACH LEWICY REGRESYWNEJ
}

\begin{abstract}
W nauce nie maja przekonania prawa obywatelstwa (...): dopiero gdy zdecyduja się one zstąpić do skromności hipotezy, tymczasowego stanowiska doświadczalnego, regulatywnej fikcyi, można im przyznać dostęp do królestwa poznania (...).
\end{abstract}

Fryderyk Nietzsche (2006: §344)

Ideał tkwi w naszych myślach niewzruszenie. (...) Weszliśmy na gładki lód, gdzie brak tarcia, i gdzie warunki sa zatem w pewnym sensie idealne; ale z tego właśnie powodu nie umiemy tam chodzić. Chcemy chodzić, a więc potrzeba nam tarcia. Zatem z powrotem na szorstki grunt!

Ludwig Wittgenstein (2000: 70-71)

\section{Abstract \\ Political correctness above all? A few remarks on the antiscientific inclinations of the re- gressive left}

The objective of this essay is to present the "regressive left" as an anti-scientific ideological movement which seeks to supersede intellectual integrity as the chief value in the academic sphere by the normative prerequisites of political correctness. In the first section I will try to sketch a general conceptualization of the term "regressive left" itself and name a few examples in order to demonstrate how its representatives and followers tend to restrict freedom of speech in the areas of research and teaching, as well. In the second section I will try to grasp the theoretical roots of this ideology from the perspective of the history of ideas, with an emphasis on the thoughts of Herbert Marcuse and Michel Foucault. Finally, in the last section I will characterize the "regressive left" as a movement based on resentment as understood by Max Scheler.

Key words: regressive left, academic sphere, freedom of speech, science, resentment 


\section{Lewica regresywna: próba konceptualizacji i zarys problemu}

W swoich Dziesięciu tezach o socjologii, polemice dedykowanej obronie „socjologii rozumnej i użytecznej”, Piotr Sztompka (2012: 7) zidentyfikował „dwa nowe poważne zagrożenia dla socjologii”. Pierwsze to zdaniem polskiego uczonego „postmodernizm głoszący niemożliwość naukowego badania społeczeństwa ze względu na jego rzekomą fragmentaryczność, atomizację, płynność, przypadkowość zmian" (Sztompka 2012: 7). Warto zaznaczyć, iż jeszcze dekadę wcześniej, Sztompka (2002: 21) przewidywał rychłe przeminięcie owej „dewiacji myślowej”. Z kolei drugie zagrożenie to zdaniem Sztompki "lewacki aktywizm przynoszący ideologizację i polityzację socjologii” (2012: 7). Także tutaj sugerował on, że jest to zjawisko o charakterze schyłkowym (2012: 7). Obecnie, czyli w roku 2020, mamy już pewność, że przewidywania polskiego uczonego nie spełniły się: postmodernizm, zamiast się skurczyć i odejść w niebyt intelektualny, uległ rozmaitym mutacjom i rozwinął się w kierunku dużo bardziej radykalnych prądów o charakterze głównie post-racjonalnym; z kolei proces ideologizacji i polityzacji socjologii przybrał nie tylko na sile, ale stał się kluczowym elementem kształtującym nie tylko kadrową, ale także instytucjonalną rzeczywistość naszej dyscypliny badawczej.

Oba zaobserwowane przez Sztompkę zagrożenia nie są zjawiskami odosobnionymi, lecz tworzą swoisty tandem, który celowo dąży do zredefiniowania nauki. $Z$ tego względu zamiast mówić o dwóch oddzielnych zagrożeniach, można by uniknąć wyjątkowo pejoratywnego terminu "lewactwa” i w zamian określić omawiane tutaj zjawisko mianem „lewicy postmodernistycznej”. Kłopot z takim pojęciem polegałby z kolei na jego wieloznaczności, dlatego zdecydowałem się dla potrzeb niniejszych rozważań stosować określenie „lewicy regresywnej”. Powód jest stosunkowo prosty: mimo swojej wyraźnej pejoratywności, pojęcie to, w odróżnieniu choćby od stosowanego przez Sztompkę obraźliwego określenia „lewactwa”, wymyka się prostemu utożsamieniu z prawicowym, czyli ideologicznym atakiem światopoglądowym ${ }^{1}$, gdyż zamiast skupiać się na samej lewicowości, kładzie akcent na wsteczność intelektualną pewnej części współczesnej lewicy². Warto w tym miejscu podkreślić, iż problem „,regresywnej lewicy” bynajmniej nie polega na „lewicowości” jej przedstawicieli ani tym bardziej na jakimś bliżej niedookreślonym „lewactwie” w sensie ogólnym, lecz na postulowanym w tym kontekście regresie intelektualnym pewnej części środowisk intelektualnych angażujących się w pracę

1 Tak sformułowany atak nie posiada w moim przekonaniu żadnych naukowych walorów poznawczych.

${ }^{2}$ Zastanawiające jest, że mimo swojej wieloletniej już popularności w zakresie politycznego dziennikarstwa oraz publicznych dyskusji, pojęcie regresywnej lewicy nie doczekało się niemal żadnego zainteresowania ze strony środowiska akademickiego. Można więc sądzić, że jest pojęciem wyjątkowo nieadekwatnym, albo - przeciwnie - wyjątkowo celnym, tzn. uderzającym w samo sedno problemu i dlatego niewygodnym dla znacznej części środowiska akademickiego. Jedyne akademickie opracowanie naukowe, które jest dostępne szerszej publiczności to znakomita praca magisterska Amber Wubs z Uniwersytetu z Groningen (2019), z której będę tutaj także korzystał. 
naukowo-dydaktyczną, a także - niestety ze zbyt dużą częstotliwością - w aktywność publicystyczną.

Kluczowym aspektem dla adekwatnego zrozumienia sensu omawianego tutaj zjawiska wydaje się fakt, iż sam termin „regresywnej lewicy” nie został ukuty przez prawicowych publicystów lub polityków, lecz przez brytyjskiego aktywistę Maajida Nawaza, byłego islamistę i założyciela think tanku Quilliam, którego działalność skupia się na zwalczaniu ekstremizmu religijnego (Dulesh 2017: 10). Nawaz po raz pierwszy zastosował ten termin w swojej autobiografii zatytułowanej Radical, w której stara się ostrzec cywilizację zachodnią przed zbyt pobłażliwym traktowaniem radykalizujących się mniejszości religijnych i przy tej okazji zwraca się krytycznie do „niektórych z lewicy” (some on the left), którzy z powodu swojego bezkrytycznego przywiązania do idei wielokulturowości mimowolnie sprzyjają rozwojowi fundamentalizmu religijnego (Wubs 2019: 4; Dulesh 2017: 10). W innym miejscu Nawaz stwierdza, że regresywna lewica stanowi tę „część lewicy” (section of the left), która przez wzgląd na poprawność polityczną waha się przed podjęciem walki przeciwko bigoterii niektórych mniejszości kulturowych (Dulesh 2017: 10)․․ Pasywność ta wynika z lansowanego przez regresywną lewicę światopoglądu, według którego świat społeczny dzieli się na „prześladowców” i „prześladowanych” (Wubs 2019: 40), przy czym przynależność do jednej bądź drugiej kategorii zależy od członkostwa w określonych grupach tożsamościowych (identity groups) na gruncie identyfikacji etnicznej, religijnej, płciowej lub seksualnej konkretnej jednostki. W ten sposób na przykład wyznawcy islamu, ale także środowisko LGBT, w sposób aprioryczny wchodzą w skład zbiorowości „prześladowanej”, czyli tożsamościowej grupy „ofiar”, które wymagają specjalnej troski oraz ochrony przed grupami domniemanych „prześladowców”, czyli na przykład islamofobów i homofobów (Wubs 2019: 40). By zrealizować ten z gruntu szlachetny cel ochrony bezbronnej mniejszości przed większością, lewica regresywna gotowa jest poświęcić fundamentalne sfery wolności indywidualnej, jak choćby swobodę wypowiedzi. W ten sposób działania lewicy regresywnej grożą podkopaniem tych swobód obywatelskich, które stanowią filar wolnościowego społeczeństwa obywatelskiego.

Biorąc pod uwagę okoliczność, że do najgorliwszych przeciwników tych antywolnościowych zapędów współczesnej lewicy zaliczają się osoby publiczne (głównie ze Stanów Zjednoczonych) o poglądach świeckich, liberalnych i - co istotne - lewicowych (Wubs 2019: 25), można wnioskować, że samo stosowane przez nich pojęcie „regresywnej lewicy" wydaje się czymś w rodzaju publicznie wyartykułowanego wyrzutu sumienia tej części środowiska o poglądach niekonserwatywnych i nieprawicowych, która nie chce się godzić się na to, aby jakakolwiek opcja polityczna zawłaszczała sobie prawo do ideologiczne motywowanego wyznaczenia granic wolności słowa w sferze publicznej. Aby jednak uchwycić istotę problemu w przestrzeni akademickiej,

${ }^{3}$ W tym miejscu nie sposób nie wspomnieć o Bassamie Tibim, niemieckim politologu o syryjskich korzeniach, który już w latach dziewięćdziesiątych minionego stulecia ostrzegał świat zachodni, w szczególności Niemców, przed protekcjonalnym podejściem do ekstremizmu religijnego w imię źle pojętej tolerancji i różnorodności kulturowej (Tibi 2002). 
chciałbym posłużyć się kilkoma przykładami, które zilustrują skalę omawianego tutaj zagrożenia dla Uniwersytetu jako sfery racjonalnej i krytycznej wymiany perspektyw intelektualnych.

Profesor Gordon Klein został zwolniony z należącej do Uniwersytetu Kalifornijskiego w Los Angeles (UCLA) Anderson School of Management, ponieważ w następstwie zabójstwa George’a Floyda przez służby policyjne nie zgodził wystawiać „łagodnych” ocen studentom „afroamerykańskim”. Bezpośrednim powodem odwołania Kleina była jego rzekomo „żałośnie rasistowska” odpowiedź mailowa, w której stwierdził, że między innymi z powodu zdalnej formy nauczania w okresie pandemii nie tylko trudno byłoby mu określić pochodzenie etniczne poszczególnych studentów, ale również nie wiedziałby jak oceniać studentów o pochodzeniu mieszanym na przykład czarno-azjatyckim (David 2020). Ponadto prof. Klein odwołał się do słynnego „marzenia” Martina Luthera Kinga, aby ludzie oceniani byli na podstawie swoich cech charakteru, a nie ze względu na „kolor skóry” (David 2020). Czyżby odwołanie się do tej maksymy etycznej przelało czarę goryczy regresywnych władz uczelni UCLA? Weźmy inny, nie mniej kuriozalny przykład: kapelan z Massachusetts Institute of Technology, o. Daniel Molony, został zwolniony ze stanowiska z powodu treści wiadomości mailowej wysłanej do katolickiej wspólnoty uczelni, w której ksiądz wyraził swoje wątpliwości odnośnie medialnie lansowanej narracji, według której zabójstwo George’a Floyda było motywowane względami rasistowskimi (NBP Staff 2020). Warto podkreślić, że o. Molony w swoim liście do wiernych w sposób klarowny potępia działania policjanta i pochwala jego aresztowanie - kapelan zwraca jedynie uwagę na ewentualność zbyt pochopnej interpretacji tego tragicznego zdarzenia. Weźmy kolejny przykład: prof. John McAdams został odwołany z jezuickiej uczelni Marquette University po tym, jak na swoim blogu krytycznie odniósł się do zachowania doktorantki, pani Abbate, która w czasie prowadzonych przez siebie zajęć dydaktycznych z etyki (sic!) personalnie zaatakowała studenta, który chciał przedstawić argumenty przeciwko legalizacji małżeństw jednopłciowych (Kainz 2015). Warto dodać, że sama dyskusja na temat małżeństw jednopłciowych nie została zainicjowana przez tego studenta, tylko przez inną osobę uczestniczącą w zajęciach. Sama pani Abbate uzasadniła swoje działanie tym, że poglądy o charakterze rzekomo homofobicznym "nie są mile widziane” (Kainz 2015). Za ostatni przykład niech posłuży głośna sprawa dr. Jordana B. Petersona, psychologa z Uniwersytetu w Toronto, który w serii wystąpień na kanale na platformie YouTube sprzeciwił się kanadyjskiej ustawie Bill-C16, wymuszającej między innymi, aby wobec określonych osób stosować zaimki płciowo neutralne. Przeciwnicy Petersona uznali, że kanadyjski psycholog jest „transfobicznym bigotem, którego należy powstrzymać" (McBride 2017). Tym razem jednak zamiast uciszyć niepokornego uczonego, lewicowi zeloci nieumyślnie doprowadzili do

${ }^{4}$ Zdaniem jednego z synów Kinga, Martina Luthera Kinga III, nie chodziło o to, aby ignorować kwestię koloru skóry jako takiej, która była i wciąż pozostaje istotnym czynnikiem dyskryminacji społecznej (CBS News 2013). 
efektu odwrotnego: Peterson stał się publiczną ikoną rebelii przeciwko poprawności politycznej i zyskał popularność gwiazdy filmowej.

Ten zbiór zaledwie kilku przykładów ${ }^{5}$ dobitnie pokazuje, że w przestrzeni akademickiej regularnie dochodzi do celowego i systemowego szykanowania, uciszania oraz prób wykluczania pracowników uniwersyteckich oraz studentów jedynie za to, iż odważyli się sformułować poglądy, argumenty lub nawet zadać pytania, które kontestowały „wrażliwość" regresywnej lewicy. Także w Polsce mogliśmy w ostatnich latach zaobserwować kilka przypadków nękania pracowników naukowo-dydaktycznych rozmaitymi sankcjami z powodu tego, że w swoich wypowiedziach starali się stawić opór coraz bardziej zaciskającym się rygorom poprawności politycznej. Jak do tego doszło? Czy jesteśmy w stanie zidentyfikować procesy ideowe, które przygotowały fundament pod tę dewastację oświeceniowych standardów działalności naukowej?

Otóż konserwatyści próbują tę niekorzystną dla siebie sytuację tłumaczyć tym, że w przestrzeni akademickiej już od wielu dekad powiększa się liczebna dysproporcja kadrowa między prawicą a lewicą na korzyść tej drugiej (Klein, Stern 2009: 32). Takie ujęcie tej problematyki wydaje się jednak nieadekwatne, gdyż pomija ona dwa istotne aspekty: po pierwsze, owa tendencja demograficzna w sferze uniwersyteckiej bynajmniej nie stanowi jakościowo nowego trendu - już słynne badania w Bennington College, przeprowadzone w latach 1935-1939, wskazywały wyraźnie, że w ramach środowiska akademickiego istnieje realna presja ku poglądom o charakterze niekonserwatywnym (Kowalski 2007: 113); po drugie, istnieją pewne przesłanki ku temu, aby podejrzewać, że owe tendencje wykluczania pracowników akademickich lub studentów z powodu wyrażonych poglądów, nie są motywowane samymi poglądami lewicowymi, jak można byłoby w pierwszej chwili sądzić na gruncie przytoczonych przykładów (Beauchamp 2018). Nie sposób bowiem z góry wykluczać scenariusza, według którego to konserwatywne siły mogą lub mogłyby dążyć do pozbycia się ze środowiska akademickiego osób „niewygodnych”. Z tej przyczyny tym bardziej istotne jest ponowne podkreślenie, że krytyczna refleksja nie powinna dotyczyć samych poglądów, lecz regresywności intelektualnej, która stanowi rezultat dogłębnej erozji poznawczych i etycznych fundamentów działalności naukowej.

${ }^{5}$ W czerwcu 2020 roku powstała długa, na bieżąco aktualizująca się lista osób, które zostały odwołane (cancelled) ze sfery uniwersyteckiej z powodu wyrażania poglądów, które przez władze uczelni uznane zostały za „nieakceptowalne” (David 2020). Są to poglądy, które nie mieszczą się w tzw. Oknie Overtona (Overton Window), określające idee oraz koncepcje „bezpieczne” dla obecnego porządku publiczno-politycznego. W tym kontekście warto podkreślić, że każdy system prawny i porządek kulturowy zawiera tego rodzaju granice tolerancji - wystarczy odwołać się do kodeksu karnego Rzeczypospolitej Polski, a dokładnie do art. 256, zgodnie z którym zakazane jest wszelkiego rodzaju propagowanie treści o charakterze faszystowskim i totalitarnym. Normatywne oraz legislacyjne ograniczenia są tutaj niezbędne, aby sama tolerancja nie została skierowana przeciwko samej sobie, np. poprzez tolerowanie treści o charakterze jawnie sprzecznym z wolnym ustrojem państwowym. Problem pojawia się jednak wówczas, gdy owe granice tolerancji ulegają arbitralnemu rozszerzaniu lub zawężeniu według „wrażliwości” przedstawicieli tylko jednej opcji politycznej. 


\section{Antynaukowy dyskurs lewicy regresywnej}

Pewną naukową ilustrację tego, w jakim stopniu lewica regresywna prowadzi do jakościowej dewaluacji działalności naukowej, podważając jej status bycia sferą tworzenia oraz szerzenia racjonalnie ugruntowanej wiedzy ${ }^{6}$, była konferencja Międzynarodowego Towarzystwa Socjologicznego (International Sociological Association, ISA) w Tajpej w 2009 roku, zainicjowana przez ówczesnego wiceprezesa ISA, Michaela Burawoya. W swojej recenzji opublikowanych wyników tego właśnie wydarzenia akademickiego, Sztompka zwrócił uwagę na pewną „rewolucyjną zmianę paradygmatu, której zasięg obejmuje nauki socjologiczne - o ile nie całe społeczeństwo globalne” (2015: 336).

Według nowego paradygmatu, którego celem jest nadanie socjologii charakteru „prawdziwie globalnej dyscypliny”, socjolodzy powinni wyzwolić się z brzemienia dominacji zachodnich tradycji badawczych i otworzyć się na lokalne i alternatywne inicjatywy mniejszościowe, co z kolei zapewniłoby „równoprawny udział ośrodków naukowych z różnych krajów, a tym samym równorzędność odmiennych perspektyw i wyrugowanie uprzedzeń” (Sztompka 2015: 336). O te uprzedzenia, jak nietrudno zgadnąć, „posądzani są socjolodzy amerykańscy i europejscy” (Sztompka 2015: 336). Aby uniknąć nieporozumienia warto podkreślić, że Sztompka nie krytykuje samego wysiłku na rzecz zmniejszenia niesprawiedliwych nierówności oraz dysproporcji i określa samą inicjatywę jako przejaw „szlachetnej ambicji zasługującej na pochwałę” (2015: 337). Niemniej, przy bliższym spojrzeniu okazuje się, że cały ten rewolucyjny paradygmat wyzwoleńczy i emancypacyjny polega na dyskursie, który zamiast w sposób twórczy rozwijać i korygować racjonalnie uzasadnione koncepcje naukowe „rodzi chaos i nieporozumienia, jest nośnikiem emocji, a nie precyzyjnych znaczeń” (Sztompka 2015: 337). Naukowy wymóg opisu i argumentacji zostaje tutaj zastąpiony przez sformułowania ideologiczne, wartościujące i normatywne, co z kolei doprowadziło do wytworzenia osobliwego „slangu antyokcydentalizmu”, którego wizytówką tożsamościową są takie konstrukty pojęciowe jak „intelektualny imperializm”, „socjologiczna kolonizacja”, „intelektualny kolonializm”, „hegemonia Zachodu”, „hegemonia Północy” albo „perspektywa Północy zamaskowana jako uniwersalizm" (Sztompka 2015: 337).

Zwolennicy tego nowego paradygmatu, którzy określają siebie samych jako przedstawicieli „socjologii krytycznej”, nie tylko forsują dyskurs, w którym nie sposób odnaleźć merytoryczne argumenty (Sztompka 2015: 338), ale ponadto kreują atmosferę własnej nietykalności intelektualnej: kto bowiem ośmieli się zastosować rzekomo wielbione przez owe środowisko narzędzie krytyki do nich samych, temu grożą rozmaite epitety będące prostym odwróceniem wymienionych wyżej pojęć: „imperialista”, „kolonizator”, "hegemon”. Mamy więc do czynienia z taką dość osobliwą formą „krytyki”, która - jak na ironię - sama zdaje się nie podlegać żadnej ocenie krytycznej. Ten fundamentalny brak

${ }^{6}$ Z powodu istotnego wpływu, jaką myśl społeczna z Niemiec miała dla rozwoju socjologii w XIX i XX wieku, warto może przypomnieć, że w języku niemieckim nauka to Wissenschaft - czyli, w dosłownym tłumaczeniu, zajmuje się tworzeniem wiedzy, a nie opinii lub poglądów. 
autokrytycyzmu ze strony przedstawicieli „socjologii krytycznej” (bardzo potrzebnej w czasach rozrastającego się do granic absurdu populizmu praktykowanego przez niemal wszystkie strony sceny politycznej) można tłumaczyć trzema błędami o charakterze pryncypialnym: po pierwsze, lansowanie egalitaryzmu w sferze akademickiej, która z racji swojej działalności oświatowej musi stanowić sferę elitarną; po drugie, utożsamianie faktycznej różnorodności zjawisk społeczno-kulturowych z uznaniem słuszności relatywizmu poznawczego; po trzecie, uporczywe ignorowanie ważności rozdzielania fazy heurystycznej od fazy dowodowej w samym procesie badawczym, co z kolei powoduje, że "przeczucia” poszczególnych badaczy nie zostają zastąpione faktami, a hipotezy nie ustępują pola „argumentacji teoretycznej i uzasadnionym prognozom” (Sztompka 2015: $346)^{7}$. Konkludując: w wypadku „socjologii krytycznej” bynajmniej nie mamy do czynienia z „krytycznym” dyskursem naukowym, lecz „z namiętną debatą", która zasługuje jedynie na miano „socjologii ideologicznej” (Sztompka 2015: 338-339).

Z kolei krytyczne uwagi Sztompki pod adresem socjologii ideologicznej (czyli antykrytycznej) są niezwykle istotne dla zrozumienia omawianej tutaj kwestii regresywnej lewicy i jej destruktywnego wpływu na rzeczywistość akademicką. Owa dewastacja polega na jakościowym regresie intelektualnym, w którym poprawność intelektualna ustępuje pola poprawności politycznej. Warto zaznaczyć, że poprawność polityczna nie musi co do swojej treści w sposób konieczny przeczyć poprawności intelektualnej niemniej warto podkreślić, że w razie ich konfliktu poprawność polityczna zdaje się $\mathrm{z}$ powodu swojej instytucjonalnej normatywności stanowić siłę nadrzędną $\mathrm{w}$ stosunku do poprawności intelektualnej, która w ostatecznym rozrachunku zawsze pozostaje całkowicie uzależniona od uczciwości poszczególnych przedstawicieli środowiska akademickiego. O tej asymetrii siły oddziaływania świadczyć może choćby okoliczność, na którą zwraca uwagę Robert Maranto (2020: 43-56): presja wynikająca z wdrażania zasad poprawności politycznej w proces badawczy i zajęcia dydaktyczne nie tylko utrudnia pracownikom naukowym podążanie za prawdą jako naczelną wartością poznawczą, ale także podkopuje wsparcie publiczne dla samej działalności akademickiej jako takiej. Z kolei dla samych nauk społecznych rezultaty okazują się najbardziej katastrofalne wówczas, kiedy wiedza o społeczeństwie ulega z powodu tego regresu poznawczej redukcji (Geser 2008). Można posłużyć się tutaj ilustracją, że od lat 90. minionego stulecia

7 Warto zauważyć, że w swojej bezpośredniej odpowiedzi do Sztompki, sam Burawoy (2015: 353), powołując się na rozmaite osobistości z obszaru filozofii nauki i poznania (między innymi na Poppera, Kuhna, Habermasa) stwierdza, że „heurystyka” i „uzasadnienie” nie mogą być precyzyjnie od siebie oddzielone, gdyż sama nauka „stanowi wytwór społeczeństwa” i związku z tym nie może być traktowana jako „zewnętrzna wobec społeczeństwa”. Zastanawiające jest to, że światowej klasy socjolog w swojej odpowiedzi zamieścił aż dwa błędy logiczne: argument $z$ autorytetu (zdaniem Burawoya chyba samo podanie nazwisk wymienionych przez niego wybitnych filozofów powinno uciszyć rzekomy "pozytywizm” Sztompki) oraz sofizmat rozszerzenia (Sztompka nigdzie nawet nie zasugerował, że można lub należy oddzielać naukę od społeczeństwa - wprost przeciwnie!). Ale z drugiej strona można by też zapytać: dlaczego Burawoy i jego kompania mieliby się w ogóle przejmować logiką, skoro ona także jest „wytworem społecznym" (o charakterze zapewne władczym i represyjnym)? 
badacze stronią przed odniesieniem danych kryminologicznych do takiej zmiennej jak pochodzenie etniczne przestępców, albowiem takie ujęcie problematyki - zwłaszcza w sytuacji ewentualnego potwierdzenia się pewnych korelacji między zmiennymi - mogłoby potencjalnie stanowić w odbiorze społecznym pretekst dla podtrzymywania lub nawet wzmocnienia negatywnych stereotypów etnicznych (Geser 2008). Krótko mówiąc, ewentualność poznania prawdy niewygodnej z perspektywy poprawnie politycznie ujętej „wrażliwości społecznej” powoduje, że sam proces tworzenia i dystrybuowania wiedzy zostaje apriorycznie ograniczany. Te same zapędy zdają się także kiełkować w zakresie dydaktyki, jak pokazuje choćby niedawne wydarzenie z Uniwersytetu Stanu Iowa: prof. Chloe Clark zamieściła w swoim sylabusie przedmiotowym ostrzeżenie dla studentów, że krytyczne podjęcie takich tematów jak aborcja, małżeństwa jednopłciowe lub ruch Black Lives Matter grozi usunięciem z kursu lub niezaliczeniem przedmiotu (Chasmar 2020). Szczęśliwie władze uczelni w tej wyjątkowo bezceremonialnej próbie odebrania studentom swobody myśli i wolności słowa, zmusiły nadgorliwą prowadzącą zajęcia do skreślenia tego „ostrzeżenia” z sylabusu przedmiotu.

Jak wytłumaczyć te zjawiska na gruncie teorii społecznej oraz z perspektywy historii idei? W celu zrozumienia tych procesów musimy się raz jeszcze cofnąć do źródłowej definicji „lewicy regresywnej”. Nawaz określił tym mianem tych, którzy w sposób bezkrytyczny stawiają interes zradykalizowanej i niebezpiecznej mniejszości ponad interes większości. Z kolei Sztompka (2015:346) podkreślił, że w sferze akademickiej rzekoma troska o mniejszości zostaje wykorzystywana do tego, aby podważyć naczelną wartość nauki, jaką jest „poszukiwanie uniwersalnej prawdy”. Wspólnym mianownikiem w obu sytuacjach zdaje się to, że domniemane potrzeby oraz interesy mniejszości stanowią wyznacznik norm działania. Jak to możliwe? Otóż w swojej refleksji nad niemożnością Zachodu do zintegrowania mniejszości muzułmańskiej, Bassam Tibi (2002: 43) zwrócił uwagę na to, że ideowe podwaliny tej niemocy wywodzą się z teorii krytycznej Szkoły Frankfurckiej, której przedstawiciele, jego zdaniem, błędnie utożsamili krytykę z negacją. Otwarcie się na obce prądy intelektualne ma się zgodnie z tak pojętą „krytyką” odbywać nie tyle w dialogicznym porozumieniu, ile kosztem porzucenia fundamentalnych zachodnich wartości kulturowych. Przedstawiciele Nowej Lewicy wiedzieli jednak, że podkopanie aksjologicznych i epistemologicznych fundamentów kulturowych będzie mogło zostać zrealizowane jedynie przez „nowy Podmiot historyczny”, który z racji swojego subiektywnego poczucia krzywdy oraz obiektywnej kondycji wykluczenia nie będzie miał oporów w przeciwstawianiu się obowiązującym normom społecznym (Marcuse 1991: 308). Tym „nowym Podmiotem” mieli się stać od lat 60. i 70. XX wieku „odmieńcy” i „outsiderzy”, czyli mniejszości kulturowe, etniczne, seksualne, których animowanie do buntu miało doprowadzić do upadku „normalnych” zasad funkcjonowania społeczeństwa (Marcuse 1987: 48-49). Ten proces „Wielkiej Odmowy” (Marcuse 1998: 164) dla przyjętych norm i wartości społecznych spowodował, że już w połowie lat siedemdziesiątych Michel Foucault z zadowoleniem stwierdził, iż zanegowany w toku rewolucji kulturowej porządek instytucjonalny zaczął się cechować „ogólną sypkością gruntów" (Foucault 1998: 18). W ten sposób utorowano drogę do odkrywania tego, co 
Foucault określał mianem „poddanej wiedzy”, czyli takiej, która z powodów przyjmowania racjonalnych paradygmatów oświeceniowych była dotychczas zdyskwalifikowana i wyrzucona poza obieg dyskursu naukowego (1998: 20). Bunt mniejszości został więc uzupełniony przez „bunt wiedzy” przeciwko „efektom centralistycznej władzy, związanej z instytucją i funkcjonowaniem zorganizowanego dyskursu naukowego w społeczeństwie takim jak nasze" (Foucault 1998: 21).

Nie ma tu miejsca na to, aby pod względem historycznym dodatkowo zgłębić analizę tej rewolty przeciwko „normalności” i „racjonalności” w kulturze zachodniej. Wystarczy zaznaczyć, że wymienione wcześniej za Sztompką dwa zagrożenia dla nauk społecznych bynajmniej nie są problemami nowymi, lecz stanowią rezultat wieloletniej presji na gruncie instytucjonalnym. Pod postmodernistycznym szyldem rzekomego zerwania z „wielkimi opowieściami”, tzw. metanarracjami, co miało skutkować przyrostem „bycia i radości, jakie wynikają z wynajdywania nowych reguł” (Lyotard 1998: 24), ukształtowana została cała sieć rewolucyjnych opowieści mniejszościowych, niczym mininarracji, które w ścisłym ideologicznym zespoleniu położyły podwaliny pod globalną redefinicję podstawowych parametrów tworzenia i dystrybucji wiedzy w systemie oświatowym. Paradoksalnie więc całościowy splot forsowanych mini-narracji uzyskał rangę zakamuflowanej metanarracji, co z kolei skutkowało tym, że poszukiwanie prawdy musiało ustąpić pola romantyczno-rewolucyjnej opowieści, która w swojej wspaniałomyślności koryguje rzekomo złowrogie nawyki instytucji oświatowych do marginalizowania i wykluczania tego, co „inne”, „obce”, „dziwne”, „alternatywne” itd. Ktoś mógłby mylnie uznać, że oto doświadczamy skutków postulowanego przez Fryderyka Nietzschego niemal półtorej wieku temu „przewartościowania wszystkich wartości”. Taka intuicja może się przynajmniej na pierwszy rzut oka wydawać zasadna, gdyż to właśnie myśl Nietzscheańska nierzadko bywa przedstawiana jako filozoficzne preludium postmodernizmu. Niemniej, postaram się w ostatniej części niniejszych rozważań sformułować tezę przeciwną.

\section{W miejsce wniosków - niepoprawna politycznie teza}

Wykładni lewicy regresywnej, opartej na błędnych założeniach egalitaryzmu, relatywizmu i subiektywizmu, Sztompka przeciwstawił formułę: „perfekcja jest ważniejsza od równowagi” (2015: 336). Na czym polega „perfekcja” w zakresie dyscypliny naukowej socjologii, a także innych nauk społecznych? Otóż Sztompka przekonuje, że socjologia „jest nauką o szczególnym statusie, zawieszoną pomiędzy nauką w sensie przyrodniczej science, humanistyką i sztuką" (2012: 8). Oznacza to, że socjologia stara się nie tylko połączyć ściśle naukowe dążenie do uzyskania uniwersalnych prawd o społeczeństwie z wrażliwością na kulturowe znaczenia i sensy, ale także kładzie nacisk na kreatywność i estetyczne walory swojego przekazu (Sztompka 2012: 8). Tylko w połączeniu wszystkich tych cech, socjologia może sobie rościć pretensje do tego, aby swoje raison d'être uzasadnić rzeczywistym dostarczaniem ,intelektualnego rozpoznania dla czynienia życia ludzi lepszym” (Sztompka 2012: 11). Jest to o tyle istotne, o ile wcześniej przytoczone 
nawoływanie Sztompki do pozostania wiernym koncepcji „prawdy uniwersalnej” mogłoby zostać mylnie odebrane jako naiwny postulat quasi-metafizyczny lub, jak zarzuca mu Burawoy (2015) - „pozytywistyczny”. Chciałbym ten problem krótko rozwinąć na tle rzekomego związku postmodernizmu z filozofią Nietzschego.

Otóż można się z wieloma aspektami filozofii Nietzschego nie zgodzić, gdyż znaczna część jego nierzadko personalnie motywowanych ataków na metafizykę, chrześcijaństwo i moralność zdaje się miejscami przesadzona do granic groteskowości (Sloterdijk 2014: 52-68). Niemniej to właśnie ta bezkompromisowość niemieckiego filozofa spowodowała, że był on skłonny, jak mało kto ,do bezpośredniego poświęcenia się najbardziej fundamentalnym problemom nowoczesnej kultury zachodniej, w tym także kwestii kondycji nauki. Nietzsche zaznaczył, że nauka w erze nowoczesnej pozostała, wbrew swoim oświeceniowym hasłom, wierna temu metafizycznemu idealizmowi, który unika zmierzenia się z materialną i dynamiczną rzeczywistością świata jako sfery nieustającej zmienności i wieloznaczności procesu życiowego (2010b: III $₫ 25$ ). Z tego powodu nowoczesne pojęcie „prawdy” pozostaje niewspółmierne z twardą, empiryczną i brutalną rzeczywistością życia, przyrody oraz dziejów (Nietzsche 1999: $\$ 15$; Nietzsche 2006 : $\$ 344$ ). Warto tutaj podkreślić, iż Nietzsche bynajmniej nie odrzuca samej działalności naukowej jako takiej, lecz stwierdza, że człowiek nowoczesny wciąż zdaje się najbardziej zaabsorbowany poszukiwaniem wiary w coś „stałego” (2006: \$347) aniżeli wiedzy, która zawsze opiera się na metodycznym (1999: $\$ 13)$ i perspektywicznym (2010a: Przedmowa, $\$ 6$ ) podejściu do rzeczywistości, dlatego nigdy nie może utwierdzić człowieka $\mathrm{w}$ jednym trwałym przekonaniu. Konsekwentnie, autor Wiedzy radosnej uznawał gotowość człowieka do zerwania z pragnieniem „pewności” (niem. Gewissheit) za przejaw jego siły, aby na gruncie zawsze niepełnej i chwiejnej wiedzy dążyć do indywidualnego samostanowienia (2006: \$347). Z kolei kurczowe trzymanie się „prawdy” w geście quasi-religijnym Nietzsche pojmował jako oznakę osłabienia woli życiowej (2006: \$347). W ten sposób Nietzsche ostrzegał przed takim rozwojem nowoczesnej nauki, która pod płaszczykiem deklaratywnego zerwania ze złudzeniami metafizyki, byłaby rodzajem dekadenckiego eskapizmu, czyli ucieczką przed złożoną rzeczywistością życia w stronę idealizmu.

Powróćmy ostatni raz do problemu lewicy regresywnej. Jest rzeczą godną pochwały, że większość przedstawicieli nauk społecznych i humanistyki stara się w zakresie swoich badań zerwać $\mathrm{z}$ naiwną wiarą $\mathrm{w}$ „prawdę" $\mathrm{i}$ próbuje swoje perspektywy teoretyczne odnieść do szerszego, globalnego kontekstu innych form wiedzy, które z powodu zbyt mocnej centralizacji systemu oświaty wokół cywilizacji zachodniej mogły faktycznie być przez wieki marginalizowane. Na tym, przy wszystkich swoich niewątpliwych przywarach, polega istotny wkład postmodernizmu do rozwoju humanistyki i nauk społecznych. Niestety, problem w tej próbie rzekomego otwarcia się na „inność” polega na tym, że

${ }^{8}$ Chciałbym zaznaczyć, że nie każda wiara w prawdę musi być naiwna, jak chciał tego samozwańczy antychrześcijanin Nietzsche. O tym, jak z perspektywy chrześcijańskiej metafizyki pojęcie prawdy zostało w toku myśli nowoczesnej zmienione i doprowadzone do swojego własnego przeciwieństwa, pisze np. Joseph Ratzinger (2012). 
proces ten oparty jest na prostej wymianie jednego ideału na inny: o ile nowoczesny dyskurs naukowy kierował się ku ideałowi „prawdy” w ujęciu postmetafizycznym, o tyle współcześnie zagospodarowanie próżni metafizycznej po upadku „wielkich narracji” zostało oddelegowane do antyintelektualnych nastrojów, które w miejsce autentycznie krytycznej refleksji nad instytucjonalnie narzuconymi „prawdami” dążą do bezkrytycznego przyjmowania i promocji narracji o charakterze antyintelektualnym, która dąży do wykluczenia kryteriów racjonalności z obszaru nauk społecznych i humanistyki.

Dlatego zamiast wniosków, chciałbym na koniec niniejszych rozważań zaryzykować sformułowanie pewnej tezy dotyczącej ukrytych intencji lewicy regresywnej, które chowają się za deklaratywną otwartością jej przedstawicieli. Otóż twierdzę, że pod płaszczykiem szlachetnej walki o „prawa mniejszości” kryje się motywacja, którą Max Scheler (2008), odnosząc się do myśli Fryderyka Nietzschego, ujął jako resentyment. Wielką zasługą Schelera jest to, że uniezależnił on samą koncepcję resentymentu od, jak trzeba przyznać, miejscami niedorzecznych ram historycznych, które owemu pojęciu nadał sam Nietzsche (Joas 1997: 37-57). Resentyment można najkrócej scharakteryzować jako „duchowe samozatrucie” wynikające z napięcia między uczuciem nienawiści i żądzą zemsty, a paraliżującym poczuciem niemocy (Scheler 2008: 50). Ten stan psychiczny przekłada się na obniżoną wartość jednostki mającej poczucie niemożności wyrównania krzywd. Na skutek owego egzystencjalnego napięcia jednostka przepełniona resentymentem ulega „złudzeniu aksjologicznemu”, które Scheler charakteryzuje jako „pozbawioną pozytywnych celów krytykę wszystkiego” (2008: 23). Ta zupełnie niekonstruktywna krytyka co prawda kamufluje się jako walka ze „złem” - to deklaratywne przywiązanie do szlachetnego celu, jakim jest „usunięcie zła” stanowi jednak, jak zauważa Scheler, jedynie „pretekst do tego, by się w ogóle wypowiedzieć” (2008: 24). W konsekwencji, w nawiązaniu do wcześniejszej uwagi Tibiego pod adresem Szkoły Frankfurckiej, jednostka przepełniona resentymentem odnajduje radość w „czystej negacji” i w „czystym potępianiu” społeczeństwa, które wini za swoje niepowodzenia życiowe. Dlatego zasadniczym przedmiotem negacji są obowiązujące „kryteria słuszności” w zakresie zarówno aksjologicznym, jak i epistemologicznym. Z racji braku jakiegokolwiek pozytywnego i zarazem realnego punktu odniesienia, resentyment zdaje się szczególnie silnym przejawem ucieczki przed rzeczywistością, co z kolei objawia się tym, że jednostka będąca pod władzą resentymentu w sposób bezkrytyczny afirmuje nierealne, mityczne czy też fantastyczne obszary „historycznej przeszłości” (Scheler 2008: 49). Nierzadko jednak taka romantyczna postawa kierować się może ku wyimaginowanej przyszłości w postaci utopii. Jak widać, lewica regresywna spełnia niemal każdą wymienioną przez Schelera cechę resentymentu jako skłonności do eskapizmu na gruncie totalnej negacji.

Konkludując: wsteczność lewicy regresywnej nie wynika z jej lewicowości (co zdaje się sugerować niefortunny termin „lewactwa”, który powinien w przekonaniu autora zniknąć z przestrzeni debaty akademickiej), lecz wiąże się bezpośrednio z resentymentem tych przedstawicieli środowiska akademickiego, którzy z powodu poczucia własnej niemocy intelektualnej oraz przywiązania do nienaukowych poglądów o charakterze ideologicznym bezkompromisowo dążą do ograniczenia wolności zarówno badawczej, 
jak i dydaktycznej. Pojawia się więc widmo ukształtowania się całkowicie upolitycznionego Uniwersytetu, w którym spór intelektualny zostanie ostatecznie zastąpiony wojną ideologiczną, która z kolei doprowadzi do dewastacji samych intelektualnych oraz aksjologicznych podstaw pracy naukowej, czyli wiary w siłę rozumu z jednej strony, oraz pielęgnacji krytycznego dystansu w stosunku do wszelkich pozanaukowych wierzeń i poglądów o charakterze politycznym i religijnym, z drugiej. Warto podkreślić, iż konflikt ideologiczny już teraz powoduje, że działaniom sprzeciwiającym się politycznemu aktywizmowi środowisk regresywnych towarzyszy także irracjonalna aura skrajnego konserwatyzmu, którego przebudzenie w nie mniejszym stopniu oddala nas od rzetelności naukowej oraz uczciwości intelektualnej. W takim „klimacie” niezwykle trudno promować wartość racjonalnej debaty, choćby na gruncie dydaktycznym, albowiem to właśnie nieprzypadkowo wszelkie przejawy rozumu stały się bezpośrednimi ofiarami toczącej się wojny światopoglądowej na Uniwersytecie. Niemniej inna droga aniżeli promocja nauki w swojej najczystszej, czyli filozoficznej postaci, nie istnieje: stawką w omówionym tutaj konflikcie jest sama tożsamość socjologii jako nauki społecznej. Albowiem, jak przestrzegał Émile Durkheim w swoich słynnych Zasadach ponad wiek temu, dopóki socjologia nie przestanie się mieszać do walk partyjnych, dopóty poprzestaje ona "na opracowywaniu z większą, niż czyni się to potocznie, dozą logiki obiegowych idei i w rezultacie nie odznacza się żadną specjalną kompetencją, nie ma prawa przemówić dostatecznie głośno, by zmusić do milczenia namiętności i przesądy” (2012: 188).

\section{Bibliografia}

Acevedo D. (2020). Tracking "Cancel Culture" in Higher Education. National Association of Scholars; https://www.nas.org/blogs/article/tracking-cancel-culture-in-higher-education (dostęp: 24.08.2020).

Beauchamp Z. (2018). Data Shows a Surprising Campus Free Speech Problem: Left-Wngers Being Fired for Their Opinions. „Vox”; https:/www.vox.com/policy-and-politics/2018/8/3/17644180/ political-correctness-free-speech-liberal-data-georgetown (dostęp: 12.08.2020).

Burawoy M. (2015). Ostatni pozytywista, tłum. B. Walczyna. „Studia Litteraria Historica”, 3-4: 350-363; doi:https://doi.org/10.11649/slh.2015.020 (dostęp: 12.08.2020).

CBS News (2013). The 1963 March on Washington Told 50 Ways: Martin Luther King Jr's „I Have a Dream Speech" Riveted Crowd; https://www.cbc.ca/news2/interactives/dream/ (dostęp: 24.08.2020).

Chasmar J. (2020). Iowa State Professor Bans Arguments against Black Lives Matter, Abortion. "The Washington Times”; https://www.washingtontimes.com/news/2020/aug/19/chloe-clark-iowa-state- professor-bans-arguments-ag/ (dostęp: 24.08.2020).

David J. (2020). Tracking "Cancel Culture" in Higher Education. National Association of Scholars, Aug. 21; https://www.nas.org/blogs/article/tracking-cancel-culture-in-higher-education (dostęp: 24.08.2020).

Dulesh S. (2017). The Regressive and Dialectics. „Humanist Perspectives”, 202: 10-18. 
Durkheim É. (2012). Zasady metody socjologicznej, tłum. J. Szacki. PWN, Warszawa.

Geser H. (2008). Political Correctness: Mental Disorder, Childish Fad or Advance of Human Civilization?; https://geser.net/pc.pdf (dostęp: 24.08.2020).

Foucault M. (1998). Trzeba bronić społeczeństwa. Wykłady w Collège de France, 1976, tłum. M. Kowalska. Wydawnictwo KR, Warszawa.

Joas H. (1997). Die Entstehung der Werte. Suhrkamp, Frankfurt am Main.

Kainz H. (2015), Firing Professor McAdams: When a Catholic University Collides with Political Correctness. The James G. Martin Center for Academic Renewal; https://www.jamesgmartin.center/2015/02/firing-professor-mcadams-when-a-catholic-university-collides-with-political-correctness/ (dostęp: 24.08.2020).

Klein D.B., Stern C. (2009), By the Numbers: The Ideological Profile of Professors, w: R. Maranto, R.E. Redding, F.M. Hess (eds.), The Politically Correct University. Problems, Scope, and Reforms, the AEI Press, Washington, D.C.: 15-37.

Kowalski R.M. (2007). The Bennington College Study, w: R.F. Baumeister (ed.), Encyclopedia of Social Psychology. Sage Publications Inc., Thousand Oaks: 113-115.

Lyotard J.F. (1998). Postmodernizm dla dzieci, tłum. J. Migasiński. Fundacja Aletheia, Warszawa.

Marcuse H. (1987). Konterrevolution und Revolte, w: H. Marcuse, R. Wiggershaus, Schriften, Band 9. Konterrevolution und Revolte. Zeit-Messungen. Die Permanenz der Kunst. Suhrkamp Verlag, Frankfurt am Main.

Marcuse H. (1991). Człowiek jednowymiarowy. Badania nad ideologia rozwiniętego społeczeństwa przemysłowego, tłum. S. Konopacki et al.; W. Gromczyński (tekst oprac. i wstępem poprz.). PWN, Warszawa.

Marcuse H. (1998). Eros i cywilizacja, tłum. H. Jankowska, A. Pawelski. Warszawskie Wydawnictwo Literackie Muza, Warszawa.

McBride J. (2017). The Pronoun Warrior. „Toronto Life”, January 25; https://torontolife.com/ city/u-t-professor-sparked-vicious-battle-gender-neutral- pronouns/ (dostęp: 24.08.2020).

NBP Staff (June 19 2020), Here's What the M.I.T. Catholic Chaplain Got Fired Over. „New Boston Post. The Hub of Conservative Thought"; https://newbostonpost.com/2020/06/19/ heres-what-the-m-i-t-catholic-chaplain-got- fired-over/ (dostęp: 24.08.2020).

Nietzsche F. (1999), Antychrześcijanin. Przekleństwo chrześcijaństwa, tłum. G. Sowiński. Nomos, Kraków.

Nietzsche F. (2006). Wiedza radosna (La gayascienza), tłum. L. Staff. Wydawnictwo Zielona Sowa, Kraków.

Nietzsche F. (2010a). Ludzkie, arcyludzkie, tłum. K. Drzewiecki. Wydawnictwo Vis-à-Vis/Etiuda, Kraków.

Nietzsche F. (2010b). Z genalogii moralności. Pismo polemiczne, tłum. L. Staff; J. Wroński, T. Słowiński (red.). Nietzsche Seminarium, Łódź-Wrocław; http://nietzsche.ph-f.org/dziela/ fn_gm.pdf (dostęp: 12.08.2020).

Ratzinger J. (2012). Wprowadzenie do chrześcijaństwa, tłum. Z. Włodkowa. Wydawnictwo Znak, Kraków.

Scheler M. (2008). Resentyment a moralności, tłum. B. Baran. Fundacja Aletheia, Warszawa. 
Sloterdijk P. (2012). Du mußtdein Leben ändern. Über Anthropotechnik. Suhrkamp Taschenbuch Verlag, Frankfurt am Main.

Sztompka P. (2002). Socjologia. Analiza społeczeństwa. Znak, Kraków.

Sztompka P. (2012). Dziesięć tez o socjologii. „Nauka”, 4: 7-15.

Sztompka P. (2015). Kolejna socjologiczna utopia, tłum. B. Walczyna. „Studia Litteraria Historica", 3-4: 335-349.

Tibi B. (2002). Europa ohne Identität? Leitkulturoderv Wertebeliebigkeit. Siedler, München.

Wittgenstein L. (2000). Dociekania filozoficzne, tłum. B. Wolniewicz. Wydawnictwo Naukowe PWN, Warszawa.

Wubs A. (2019). Regressive Left. An Examination of the Regressive Left Discourse in the Period 2012-2017. MA Thesis Religion, Conflict, and Globalization, University of Groningen; https://ggw.studenttheses.ub.rug.nl/484/1/1819-RCG\%20Wubs\%2C\%20A.\%20Masterthesis.pdf (dostęp: 31.08.2020). 